\title{
CORRIGENDUM
}

Volume XIIII (1950), page 57, note 67 .

In the article "Paul of Constantinople," Section IV and the sentence to which Note 67 refers, the words "northwards" and "for delivery on the coast of Asia Minor" should be deleted. Père Peeters merely argues that the raft afforded escape from Tyre. In the first instance, Athanasius was carried away from his goal.

\section{Seventh Congress for the History of Religions}

The Seventh Congress for the History of Religions will be held at Amsterdam from September 4th to September 9th, 1950. Those who desire to take part should write to the Secretary, Professor C. J. Bleeker, Churchill-laan 290-I, Amsterdam. 